\title{
Biallelic DAB1 Variants Are Associated With Mild Lissencephaly and Cerebellar Hypoplasia
}

Daphne J. Smits, MD, Msc, Rachel Schot, BSc, Martina Wilke, PhD, Marjon van Slegtenhorst, PhD, Marie Claire Y. de Wit, MD, PhD, Marjolein H.G. Dremmen, MD, MSc, William B. Dobyns, MD, PhD, A. James Barkovich, MD, PhD, and Grazia M.S. Mancini, MD, PhD

Neurol Genet 2021;7:e558. doi:10.1212/NXG.0000000000000558

\section{Abstract}

\section{Objective}

We aimed to identify pathogenic variants in a girl with epilepsy, developmental delay, cerebellar ataxia, oral motor difficulty, and structural brain abnormalities with the use of whole-exome sequencing.

\section{Methods}

Whole-exome trio analysis and molecular functional studies were performed in addition to the clinical findings and neuroimaging studies.

\section{Results}

Brain MRI showed mild pachygyria, hypoplasia of the cerebellar vermis, and abnormal foliation of the cerebellar vermis, suspected for a variant in one of the genes of the Reelin pathway. Trio whole-exome sequencing and additional functional studies were performed to identify the pathogenic variants. Trio whole-exome sequencing revealed compound heterozygous splice variants in $D A B 1$, both affecting the highly conserved functional phosphotyrosine-binding domain. Expression studies in patient-derived cells showed loss of normal transcripts, confirming pathogenicity.

\section{Conclusions}

We conclude that these variants are very likely causally related to the cerebral phenotype and propose to consider loss-of-function $D A B 1$ variants in patients with RELN-like cortical malformations.

\author{
Correspondence \\ Dr. Mancini \\ g.mancini@erasmusmc.n
}




\section{Glossary}

GoF = gain of function; LoF = loss of function; PTB = phosphotyrosine binding; WES = whole-exome sequencing.

The Disabled-1 (DAB1) gene encodes a key regulator in Reelin signaling, a critical pathway mediating correct positioning of neurons within the developing brain. ${ }^{1,2}$ In mice, both Dab1 and Reln are essential for proper cortical layering during embryonic development. Binding of Reelin to the lipoprotein receptors VLDLR and APOER2 on the neuronal surface leads to phosphorylation of DAB1 and activates downstream signaling cascades. Dab1-depleted mice present with a phenotype comparable to Reelin-deficient mice, including disruption of neuronal layering in the cerebral cortex, hippocampus, and cerebellum. ${ }^{3}$

Yet, human loss-of-function (LoF) mutations in $D A B 1$ have not been described, whereas biallelic LoF mutations in RELN (OMIM \#600514) are well known to cause a similar phenotype as seen in the murine counterpart. Recessive RELN variants cause a distinctive lissencephaly, associated with prominent hypoplasia of the pons, the cerebellar hemispheres, and the vermis. ${ }^{4} \mathrm{~A}$ similar but milder phenotype is described for VLDLR (OMIM \#192977) variants. ${ }^{5}$ The only human disease related to $D A B 1$ is spinocerebellar ataxia type-37

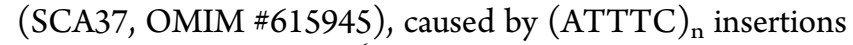
in the $5^{\prime}$ UTR of DAB1. ${ }^{6}$ Several studies show that SCA37 occurs through gain-of-function ( $\mathrm{GoF})$ mechanisms, of which only 1 is directly related to DAB1 expression because the insertion results in overexpression of $\mathrm{DAB} 1$ protein and alternative $D A B 1$ transcripts. $^{7}$

Here, we report a patient with biallelic LoF variants in $D A B 1$, presenting with RELN-like malformations including mild lissencephaly and cerebellar hypoplasia.

\section{Methods}

\section{Consent}

The study was approved by the local IRBs (Erasmus MC Rotterdam, protocol METC-2012387). Written informed consent to participate in this study was obtained from the parents of the participant.

\section{Whole-Exome Sequencing}

Whole-exome sequencing (WES) was performed on the Agilent Sure Select platform (Clinical research Exome Capture), run on HiSeq (101bp paired-end, Illumina), using the diagnostic certified pipeline of the department of Clinical Genetics, ErasmusMC, Rotterdam. The average coverage is $\sim 50 \times$. Data are demultiplexed by the Illumina Software CASAVA. Reads are mapped with the program BWA (bio-bwa. sourceforge.net/). Variants are detected with the Genome Analysis Toolkit (broadinstitute.org/gatk/). The Variant Calling File is filtered in Alissa Interpret.

\section{Sanger Sequencing}

Amplification reactions were conducted according to standard methods and purified with ExoSAP-IT (USB). Direct sequencing was performed with Big Dye Terminator chemistry (Applied Biosystems). DNA fragment analysis was performed with capillary electrophoresis on an ABI3130 Genetic Analyzer (Applied Biosystems) with the software package Seqscape (Applied Biosystems).

\section{Quantitative Reverse Transcription PCR}

Fibroblasts from skin biopsies were grown in DMEM (10\% fetal bovine serum, 1\% L-glutamine, and $1 \%$ penicillin/ streptomycin) at $37^{\circ} \mathrm{C}$ and $5 \% \mathrm{CO}_{2}$, followed by RNA isolation using the RNeasy mini kit (QIAGEN). RNA was reverse transcribed with the iScript cDNA synthesis kit (Bio-Rad Laboratories). Quantitative reverse transcription PCR was performed using iTaq Universal SYBR Green Supermix (Bio-Rad) and the following primer sequences: DAB1_rt _c307_1F:TCGGGATTGATGAAGTTTCC;DAB1_rt_c307_ 1R:AGCCTCAAACACAATGTACTGG;DAB1_rt_c67_ 2F:GAGGATGCTCTGGGCTAGG;DAB1_rt_c $\overline{6} 7$ _2 AAAGATTTTGATTCCTCCAAAGG.

\section{Data Availability}

WES data are deposited at the ISO certified diagnostic laboratory of the Department of Clinical Genetics, Erasmus MC, in respect to the family's privacy.

\section{Results}

\section{Case Report}

The affected individual was born at term after an uneventful delivery from unrelated healthy parents. In infancy, she had gastrointestinal reflux and excessive crying. She tolled over at 8 months, sat unsupported at 14 months, and walked at age 3 years. Cognitive development initially raised no concern, but during the first years, learning problems became apparent and she now attends special school (IQ: 50-60). The onset of focal epilepsy was at age 6 years; seizure semiology was loss of awareness, staring, without clear motor signs. Oxcarbazepine $(8 \mathrm{mg} / \mathrm{d})$ reduced seizure frequency, but absences persist once/ twice a week without additional signs. Physical examination at age 11 years showed mild cerebellar ataxia, oculomotor apraxia, mild dysmetria of the upper extremities, impaired tandem gait, impaired facial muscle coordination, dysarthria, instability during Romberg test, dysdiadokokinesis, squint, mild pyramidal signs, joint hypermobility, normal muscular tone, and symmetrically low deep tendon reflexes. Head circumference was -1 SD; weight and height were within the normal range. Standard EEG at age 10 years showed no epileptic activity, normal posterior activity, excess of theta and delta waves in frontopolar, 


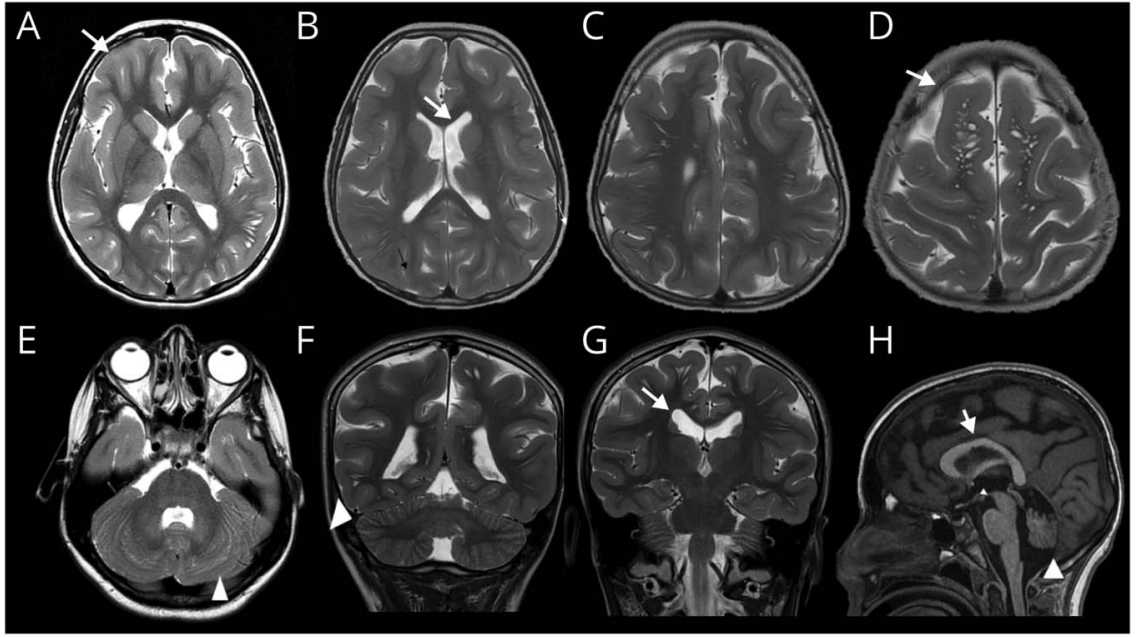

Brain MRI of the affected individual with axial T2-weighted images (A-E), coronal T2-weighted images ( $F$ and $G$ ), and midsagittal T1-weighted image $(H)$. Mild and diffuse cortical pachygyria more prominent in the frontal lobes (arrow in A and $D$ ), mildly thin corpus callosum ( $\mathrm{H}$, arrow), hypoplasia and abnormal foliation of cerebellar hemispheres ( $E$ and $F$, arrow head) and more pronounced vermis hypoplasia $(\mathrm{H}$, arrow head), enlarged perivascular spaces $(A-G)$, and lateral ventricles ( $B$ and $G$, arrow), all reminiscent of an RELN/VLDLR pattern. frontal, and temporal areas with occasional sharp waves in frontotemporal regions (left more than right), and normal photic stimulation response. Brain MRI at age 12 years showed cortical malformations reminiscent of RELN-related malformations, including mild pachygyria, i.e., decreased number of gyri with moderately thickened cortex (more prominent in the frontal lobes), mildly thin corpus callosum, enlarged perivascular spaces, and mildly enlarged lateral ventricles. The cerebellar vermis was hypoplastic and showed abnormal foliation.
Abnormal foliation was observed to a lesser extent in the cerebellar hemispheres. The pons, the basal ganglia, and the hippocampal folding were normal (figure 1).

\section{Genomic Analysis and Expression Studies}

High-resolution genomic microarrays showed normal female pattern. Sanger sequencing of RELN was normal. WES trio analysis identified compound heterozygosity for $D A B 1$ splice site variants. The first variant (Chr1(GRCh37):g.57756635C>A

Figure 2 Functional Analysis of $D A B 1$ Variants

A

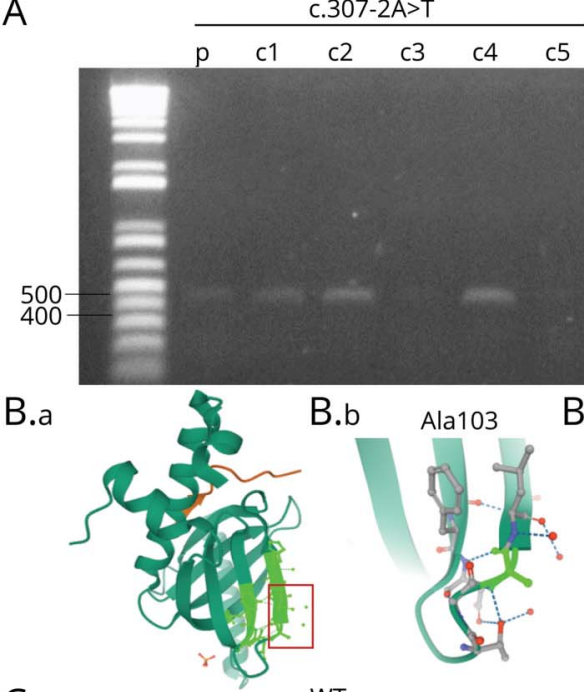

C

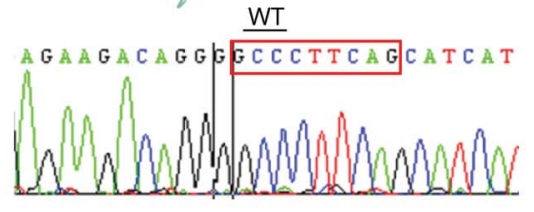

B.c Leu104

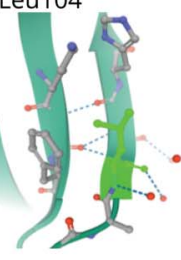

C.307-2A>T

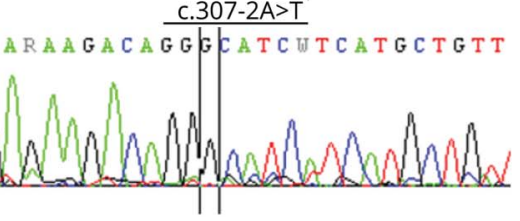

(A) RT-PCR of DAB1 mRNA from the affected individual( $p$ ) and 5 age- and sex-matched control samples(c1-5). Primers were designed to amplify a product of $450 \mathrm{bp}$ for the $67+1 \mathrm{G}>\mathrm{T}$ variant and a product of $470 \mathrm{bp}$ for the 307-2A $>$ T variant. For the $67+1 \mathrm{G}>\mathrm{T}$ variant, an alternative mRNA splice product is formed in the affected individual, which could be explained by the deletion of exon 4 (exon 4 contains 203 bp). (B) Structural model of the DAB1 PTB domain. The panel (B.a) shows the structure of the entire domain. Localization of the deleted amino acids is depicted in the other panels (B.b-B.d). (C) Sanger sequencing results of the c.307-2A>T transcript. PTB = phosphotyrosine binding; RT-PCR = reverse transcription PCR. 
NM_021080.3 c.67+1G>T, p.?) is located in the splice donor site of intron 4 and has never been reported in GnomAD. Splice prediction programs (MaxEntScan, NNSPLICE, GeneSplicer) predict an in-frame deletion of exon 4. Of interest, this deletion eliminates the ATG initiation site and the corresponding Kozak consensus sequence. Reverse transcription PCR on cDNAderived from fibroblasts confirmed that the $c .67+1 \mathrm{G}>\mathrm{T}$ variant leads to a shorter, but stable, transcript (figure $2 \mathrm{~A}$ ). The second variant (Chr1(GRCh37):g.57538089T $>$ A NM_021080.3 c.307-2A>T, r.307_315del9 p.Ala103_Gln105del) affects the splice acceptor site of intron 6, resulting in an in-frame deletion of 3 amino acids of exon 7, which are part of a $\beta$-sheet forming the highly conserved phosphotyrosine-binding (PTB) domain (figure 2B). Sanger sequencing confirmed this deletion (figure 2C). Heterozygosity was confirmed for both parents. Despite database searches (genematcher.org) and international contacts (Neuro-MIG), we did not identify another individual with a similar phenotype.

\section{Discussion}

Here, we report an individual with biallelic splice variants in $D A B 1$. Given the RELN-like phenotype at MRI and the similarities of our patient with RELN/VLDRL-associated phenotypes, we conclude that the observed $D A B 1$ variants are very likely related to the cerebral malformations in our patient. ${ }^{4,5}$ The $D A B 1$ splice variants in our patient result in alternative transcripts affecting the highly conserved PTB domain. Translation of any DAB1 isoform containing this domain from the c. $67+1 \mathrm{G}>\mathrm{T}$ transcript is unlikely because it eliminates the methionine start codon. The c.3072A $>$ Tp.Ala103_Gln105del variant results in a protein containing this domain, but with a deletion of 3 amino acids, most likely altering protein folding. Although the precise effect of this deletion on protein structure and binding capacities remains unclear, the heterozygote parent carrying the c.67+1$\mathrm{G}>\mathrm{T}$ p.? variant is healthy, supporting the additional pathogenic effect of the c.307-2A>Tp.Ala103_Gln105del variant.

In vitro, the PTB domain binds to cytoplasmic tails of the VLDLR and apoER2. This interaction is essential because binding of Reelin to these receptors induces DAB1 tyrosine phosphorylation and subsequent activation of downstream signaling pathways. Mice lacking the DAB1 PTB domain show almost complete absence of distinct cell layers in the cortex, a small and unfoliated cerebellum, and abnormal neuronal layering in the hippocampus. ${ }^{3}$

GoF mechanisms have been previously described in relation to $D A B 1$ autosomal dominant mutations, causing SCA37. ${ }^{6}$ Although our patient presents with mild cerebellar ataxia, most of the phenotypic features are very distinguishable from SCA37. ${ }^{7,8}$ The proposed mechanisms causing SCA37 (e.g., $\mathrm{DAB} 1$ overexpression, RNA foci formation) are very distinct from the effect of the LoF variants described here, which explains the phenotypic differences and the early age at onset in our patient. Our results indicate that $D A B 1 \mathrm{LoF}$ variants should be considered in patients with RELN-like cortical malformations at MRI. In addition, we propose inclusion of $D A B 1$ in diagnostic exome panels devoted to brain malformations, intellectual disability, and epilepsy.

\section{Acknowledgment}

The authors thank the patient family for participation in the study. The Neuro-MIG network, (COST Action CA16118 neuro-MIG. org), fostered interaction among the authors D.J. Smits, M. Wilke, W.B. Dobyns, A.J. Barkovich, and G.M.S. Mancini.

\section{Study Funding}

No targeted funding reported.

\section{Disclosure}

The authors report no disclosures. Go to Neurology.org/NG for full disclosures.

\section{Publication History}

Received by Neurology: Genetics September 3, 2020. Accepted in final form December 2, 2020.

Appendix Authors

\begin{tabular}{|c|c|c|}
\hline Name & Location & Contribution \\
\hline $\begin{array}{l}\text { Daphne J. } \\
\text { Smits, MD, } \\
\text { Msc }\end{array}$ & $\begin{array}{l}\text { ErasmusMC University } \\
\text { Medical Center, } \\
\text { Rotterdam, the } \\
\text { Netherlands }\end{array}$ & $\begin{array}{l}\text { Writing the draft and } \\
\text { performing the } \\
\text { experiments }\end{array}$ \\
\hline $\begin{array}{l}\text { Rachel Schot, } \\
\text { BSc }\end{array}$ & $\begin{array}{l}\text { ErasmusMC University } \\
\text { Medical Center, } \\
\text { Rotterdam, the } \\
\text { Netherlands }\end{array}$ & $\begin{array}{l}\text { Performing the } \\
\text { experiments and revising }\end{array}$ \\
\hline $\begin{array}{l}\text { Martina } \\
\text { Wilke, PhD }\end{array}$ & $\begin{array}{l}\text { ErasmusMC University } \\
\text { Medical Center, } \\
\text { Rotterdam, the } \\
\text { Netherlands }\end{array}$ & $\begin{array}{l}\text { Analysis of data and } \\
\text { revising }\end{array}$ \\
\hline $\begin{array}{l}\text { Marjon van } \\
\text { Slegtenhorst, } \\
\text { PhD }\end{array}$ & $\begin{array}{l}\text { ErasmusMC University } \\
\text { Medical Center, } \\
\text { Rotterdam, the } \\
\text { Netherlands }\end{array}$ & $\begin{array}{l}\text { Analysis of data and } \\
\text { revising }\end{array}$ \\
\hline $\begin{array}{l}\text { Marie Claire } \\
\text { Y. de Wit, MD, } \\
\text { PhD }\end{array}$ & $\begin{array}{l}\text { ErasmusMC University } \\
\text { Medical Center, } \\
\text { Rotterdam, the } \\
\text { Netherlands }\end{array}$ & $\begin{array}{l}\text { Acquisition of data and } \\
\text { revising }\end{array}$ \\
\hline $\begin{array}{l}\text { Marjolein } \\
\text { H.G. } \\
\text { Dremmen, } \\
\text { MD, MSc }\end{array}$ & $\begin{array}{l}\text { ErasmusMC University } \\
\text { Medical Center, } \\
\text { Rotterdam, the } \\
\text { Netherlands }\end{array}$ & $\begin{array}{l}\text { Analysis of data and } \\
\text { revising }\end{array}$ \\
\hline $\begin{array}{l}\text { William B. } \\
\text { Dobyns, MD, } \\
\text { PhD }\end{array}$ & $\begin{array}{l}\text { University of Minnesota, } \\
\text { Minneapolis }\end{array}$ & $\begin{array}{l}\text { Supervision, interpretation } \\
\text { of data, and revising }\end{array}$ \\
\hline $\begin{array}{l}\text { A. James } \\
\text { Barkovich, } \\
\text { MD, PhD }\end{array}$ & $\begin{array}{l}\text { University of California, } \\
\text { San Francisco }\end{array}$ & $\begin{array}{l}\text { Supervision, interpretation } \\
\text { of data, and revising }\end{array}$ \\
\hline $\begin{array}{l}\text { Grazia M.S. } \\
\text { Mancini, MD, } \\
\text { PhD }\end{array}$ & $\begin{array}{l}\text { ErasmusMC University } \\
\text { Medical Center, } \\
\text { Rotterdam, the } \\
\text { Netherlands }\end{array}$ & $\begin{array}{l}\text { Supervision, formulation } \\
\text { of research goals, } \\
\text { interpretation of data, and } \\
\text { writing the draft }\end{array}$ \\
\hline
\end{tabular}




\section{References}

1. Howell BW, Lanier LM, Frank R, Gertler FB, Cooper JA. The disabled 1 phosphotyrosine-binding domain binds to the internalization signals of transmembrane glycoproteins and to phospholipids. Mol Cell Biol 1999;19:5179-5188.

2. Zhang JH, Zhao YF, He XX, et al. DCC-mediated Dab1 phosphorylation participates in the multipolar-to-bipolar transition of migrating neurons. Cell Rep 2018;22:3598-3611.

3. Howell BW, Hawkes R, Soriano P, Cooper JA. Neuronal position in the developing brain is regulated by mouse disabled-1. Nature 1997;389:733-737.

4. Hong SE, Shugart YY, Huang DT, et al. Autosomal recessive lissencephaly with cerebellar hypoplasia is associated with human RELN mutations. Nat Genet 2000;26: 93-96.
5. Valence S, Garel C, Barth M, et al. RELN and VLDLR mutations underlie two distinguishable clinico-radiological phenotypes. Clin Genet 2016;90:545-549.

6. Loureiro JR, Oliveira CL, Mota C, et al. Mutational mechanism for DAB1 (ATTTC)n insertion in SCA37: ATTTT repeat lengthening and nucleotide substitution. Hum Mutat 2019;40:404-412.

7. Corral-Juan M, Serrano-Munuera C, Rabano A, et al. Clinical, genetic and neuropathological characterization of spinocerebellar ataxia type 37. Brain 2018;141: 1981-1997.

8. Seixas AI, Loureiro JR, Costa C, et al. A pentanucleotide ATTTC repeat insertion in the non-coding region of DAB1, mapping to SCA37, causes spinocerebellar ataxia. Am J Hum Genet 2017;101:87-103. 


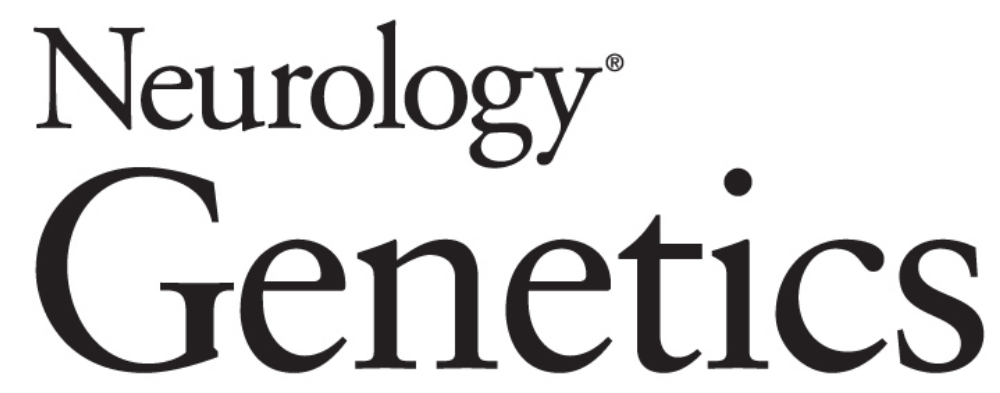

Biallelic DAB1 Variants Are Associated With Mild Lissencephaly and Cerebellar Hypoplasia

Daphne J. Smits, Rachel Schot, Martina Wilke, et al. Neurol Genet 2021;7;

DOI 10.1212/NXG.0000000000000558

This information is current as of January 21, 2021

Neurol Genet is an official journal of the American Academy of Neurology. Published since April 2015, it is an open-access, online-only, continuous publication journal. Copyright Copyright $\odot 2021$ The Author(s). Published by Wolters Kluwer Health, Inc. on behalf of the American Academy of Neurology.. All rights reserved. Online ISSN: 2376-7839.

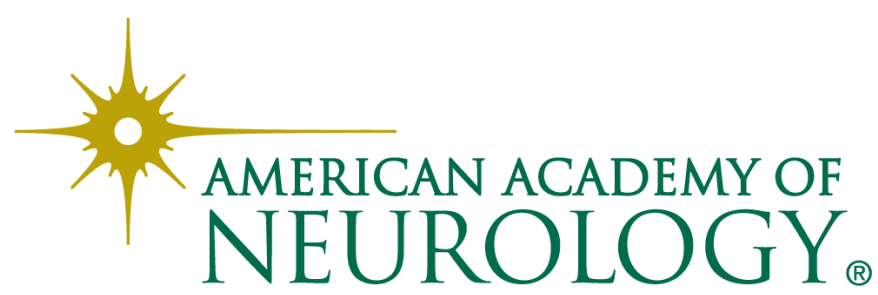




\section{Updated Information \& Services}

References

Subspecialty Collections

Permissions \& Licensing

\section{Reprints}

including high resolution figures, can be found at: http://ng.neurology.org/content/7/2/e558.full.html

This article cites 8 articles, 1 of which you can access for free at: http://ng.neurology.org/content/7/2/e558.full.html\#\#ref-list-1

This article, along with others on similar topics, appears in the following collection(s):

All Epilepsy/Seizures

http://ng.neurology.org//cgi/collection/all_epilepsy_seizures

\section{All Genetics}

http://ng.neurology.org//cgi/collection/all_genetics

Cerebellum

http://ng.neurology.org//cgi/collection/cerebellum

Developmental disorders

http://ng.neurology.org//cgi/collection/developmental_disorders

\section{MRI}

http://ng.neurology.org//cgi/collection/mri

Information about reproducing this article in parts (figures,tables) or in its entirety can be found online at:

http://ng.neurology.org/misc/about.xhtml\#permissions

Information about ordering reprints can be found online:

http://ng.neurology.org/misc/addir.xhtml\#reprintsus

Neurol Genet is an official journal of the American Academy of Neurology. Published since April 2015, it is an open-access, online-only, continuous publication journal. Copyright Copyright $\odot 2021$ The Author(s). Published by Wolters Kluwer Health, Inc. on behalf of the American Academy of Neurology.. All rights reserved. Online ISSN: 2376-7839.

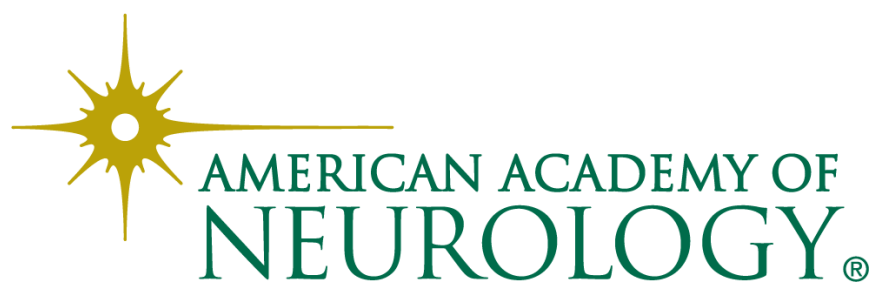

